\title{
Collaboration Through Entrepreneurship in Non Profit Organization A Study of Hoshizora Foundation, Indonesia
}

\author{
Laras Wijayanti \\ Department Social Welfare \\ Universitas Indonesia \\ Depok, Indonesia \\ laraswija@gmail.com
}

\author{
Fentiny Nugroho \\ Department Social Welfare \\ Universitas Indonesia \\ Depok, Indonesia \\ fentiny2015@gmail.com
}

\begin{abstract}
A high degree of dependency of an NGO as a nonprofit organization toward donor's funding threaten the sustainability of an organization. Revenue diversification can be an alternative for the sustainability of an organization. One of them can be supported by independency to seek funds through entrepreneurship. The limited resources in the entrepreneurship initiated by NPOs can be helped by collaborating with other parties, especially the community. The existence of participation can provide an opportunity to increase the income of the communities involved through the potential that exists in the area. Collaboration in selected entrepreneurship is expected to expand the impact not only for foundation but also for the welfare of the society. The Research used a qualitative approach. The sampling technique is nonprobability sampling with a purposive sampling. Data collection involves literature review, in-depth interview, field observation, and documentation.
\end{abstract}

Keywords: collaboration; entrepreneurship; non-profit organization; community participation

\section{INTRODUCTION}

Economic development will be pointless without increasing social wealth of community and social development will not happen without economic development. Social development approach is expected to integrate social and economic development efforts. Midgley explains that social development strategies are divided into three types: social development strategy that place individuals as the primary responsibility for promoting social development, a strategy that emphasizes the role of local communities in supporting social development, as well as government-dependent strategies in promoting social development [1]. These three different strategies have different ways of achieving the goals of social development, all of it perceived that human well-being will achieved well in the context of a comprehensive process in economic development.

Beside the government, many non-government organizations in Indonesia conduct social programs. The non-profit sector or simply the NGO has grown substantially in the past few decades and has been instrumental in meeting societal needs, but its impact to the society is still limited by its inability to sustain or scale initiatives. For future growth, they have to rely on the public and private sectors for financial support [2]. Most organizations in Indonesia depend on the external funding for their operations and management needs. In the context of growing uncertainty and competition for donations, a diversified mix of funding sources has increasingly been considered a prudent strategy for reducing unpredictability. Having a wide variety of funding streams seems like a good way to reduce the risk of losing any single source of resources [3]. The success of NPOs has been attributed to "their ability to diversify funding sources in response to current economic and political environments" [4] . NPOs are advised to adopt more entrepreneurial management approaches [5]. One of the sources of an alternative income is seeking fund independently through entrepreneurship. Through this strategy they are able to explore the potential of the surroundings and involving the local community as well. Social entrepreneurship is an alternative approach in the development of economic regarding dependency to the donor problem and stimulates entrepreneurship in community [6] .

In a research by Tan and Yoo called Social Entrepreneurship Intentions of Non-Profit Organizations with 92 nonprofit organizations in Singapore as samples revealed several factors that affect non-profit organizations in starting entrepreneurship. These factors are business leadership experiences, high organizational effectiveness and organizational innovation $[7[$. Nonprofits can be established and dissolved easily especially when they lack the human, intellectual, social, and physical capitals necessary to develop and sustain an organization [8] . Capacity building efforts help them reach the missing components for their survival and growth; yet, most of the time they need external support for building capacity [9] . This research tries to observe factor of collaboration with other party in attempt to develop entrepreneurship initiated by nonprofit organization. There are other studies on NGOs that empower society through entrepreneurship by Araniri [10] and Wicaksono [11] , the studies before are different

Corresponding author: Fentiny Nugroho 
from the Hoshizora Foundation which entrepreneurship essentially is not the main program of the foundation. The main program is to help Indonesian children who are less fortunate financially to receive education. Entrepreneurship as an alternative income in the future is expected to support the sustainability of the organization. Collaboration with other parties is needed to attain the purposes of the entrepreneurship.

The researcher is interested in seeing how the Hoshizora Foundation entrepreneurship's processes in collaboration with other parties including the community along with its challenges. Sometimes non-profit organization face constraints such the lack of resources in managing the entrepreneurship so that collaboration with other parties is needed to develop newly established entrepreneurship. Researchers want to focus on entrepreneurship whose net profit aims for the sustainability of the organization yet involves the community. Although entrepreneurship cannot ensure that non-profit organization will $100 \%$ independent financially, collaboration can increase income and social impact. Based on the consideration of the research focus of the three entrepreneurial Hoshizora Foundation, researchers will discuss more about EEC Farm. Derived from the descriptions, then the formulation of the problem in this research in the form of research questions as follows:

1. How does the Hoshizora Foundation in making collaboration in order to develop the entrepreneurship it initiates?

2. What are the benefits of collaboration in Hoshizora Foundation entrepreneurship?

\section{RESEARCH METHOD}

The research used a qualitative approach. This approach was obtained through the entrepreneurship of NGO at Hoshizora Foundation in Kalakijo tourism village, Pajangan, Bantul, Yogyakarta. The sampling technique is non-probability sampling. Informants selected based on purposive sampling are informants who pose the following criteria:

1. Hoshizora Foundation managers who know about the history of the foundation since the establishment until today and the role of Hoshizora in EEC Farm.

2. EEC Team who knows EEC Farm business model, marketing strategy, attempt to involve the society and obtained benefits.

3. The people of Kalakijo Tourism Village whom are involved in entrepreneurship.

Data collection methods used in this study includes:

1. Literature Studies/documents, using various sources start from books, journals, research results and media with relevant research topics. To obtain secondary data also conducted document / archive study.

2. In-depth Interviews
In-depth interviews with selected informants through purposive sampling techniques. Interviews in this study were conducted with semi structured interview instruments.

3. Field Observation

Observations based on research topics to find reality in the field. Observations such as EEC land and farmers.

4. Documentation / capture images according to the target and the need to complete the interview and observation results.

\section{RESULT AND DISCUSSION}

Hoshizora Foundation is a non-governmental organization with non-profit oriented based in Yogyakarta, Indonesia. When it was newly founded Hoshizora Foundation has not conducted entrepreneurship yet. Hoshizora Foundation income mostly comes from Japan's donations. Part of the sustainability plan of Hoshizora Foundation was funding from philanthropic organization in Japan. However, during the 2011 Japan earthquake and tsunami, donations to the Hoshizora Foundation decreased. The dwindling funds make this NGO start to think about entrepreneurship to get fund for operational. This experience makes the Hoshizora Foundation think of the need to develop social enterprise for the sustainability of the organization in the future. Various businesses have been run such as rental shop, clothes and takoyaki but it were not last long. The fall and rise of Hoshizora Foundation in entrepreneurship is addressed as process of learning for Hoshizora Foundation in reading the market [12].

Currently Hoshizora Foundation is focused on Environmental Education Center (ECC), amongst other social business units that contribute to the Foundation. Environmental Education Center (ECC) aimed at sustainability organization where $100 \%$ of net profits go to the Hoshizora Foundation. EEC is one of the revenue sources to embody $100 \%$ model of Hoshizora Foundation. The Hoshizora Foundation is committed to awarding 100\% donation from Kakak Bintang (child sponsorship donor) to Adik Bintang (sponsored child). With this commitment, it can increase the trust of the donating party because donation is not used for the organization's operation and management but $100 \%$ on social program.

Environmental Education Center (EEC) provides knowledge of sustainable natural farming and environmentally based education outbound. EEC's vision is to raise awareness of Indonesian community about environmental sustainability and provide opportunity for Indonesian children to learn about the environment. Furthermore, EEC educates local villagers to explore new concept of natural farming to maximize their potential, in the same time to attract middle and upper-class citizens (Indonesian and international) to come to the village to learn about natural farming. The direct target group as users of 
EEC are elementary schools (children and teachers), mid and upper SES family (domestic and international), groups/institutions (travel agents, offices), and communities (organic \& health base community).

Environmental Education Center (EEC) has three main principles: natural farming, education, social responsibility and empowerment. EEC is not only a profitable social enterprise that raises awareness of environmental sustainability, but also empower local community to practice natural farming and support Indonesian education because $100 \%$ of the profit goes to Hoshizora Foundation (www.eecfarm.com). EEC started in August 2015 and the facilities were completed in June 2016. EEC started running as a social enterprise brings revenue in July 2016.

Based on Article 3 paragraph 3 of Law No.16 Year 2001 the foundation is allowed to conduct business activities, among others, by establishing a business enterprise and/or as well as within a business enterprise. The entrepreneurial finances are separated from the foundation. The team managing entrepreneurship is separate from the management that manages the foundations' social programs. Finance includes separated wage and tax payments. As expressed by Reky Martha, President of Hoshizora Foundation:

"Our social enterprises have to pay tax therefore the expense should be separated from the foundation. It should be clear, totally separated and transparent. From the beginning it registered under PT Bintang Langit Mandiri. So the generating revenue of it is all by itself, we should pay tax, income tax"

For outbound marketing program, EEC collaborates with LPMD (Village Community Empowerment Institution) Kalakijo. LPMD also has outbound program with fun outbound as its concept. Although both of them offer outbound activity, but they have different target markets yet still can work together. EEC promotes fun outbound LPMD and vice versa. Consumers can order LPMD outbound via EEC. As expressed by Aris, Kalijoko residents:

"EEC is Environment Education Center so it focuses to wastes management, the management for the wastes, about how to plant plants properly, and seeding, so that is all about. As for us, we focus on the games. So, the education is tend to be EEC, and goes the same for EEC, and they are more detail. We have such fun program. But we can collaborate, so if they want it to be half fun and half serious then we can collaborate with EEC. As for the prize, we can use package prize, how much from EEC and how much from here. We only collaborate for this game and promotion. We also promote them, and they also promote us, as for share prize we try to make it simple"
Aside from promoting each other, they also lend each other tools. It can make the out bound program become more various and save more money for tool expense. LPMD helps if EEC lacks of human resources for outbound execution. Outbound facilitators aside from EEC staffs also collaborate with LPMD.

EEC educates local villagers to explore new concept of natural farming to maximize their potential. EEC empowers local community to practice natural farming such provides training to Kalakijo villagers about natural farming and permaculture. For example, people are taught how to sustain agriculture, how to plant seeds without plastic. EEC also recruits part time staff from villagers when there are activities that require additional human resources. As expressed by Reky Martha, President of Hoshizora Foundation as follows:

"So for all this time we provide free training to residents and children. It is limited for us for public employing. In our social work, we have our a full time staff and there are about five part time staff from the village who often help us. We are engaged. But more than that, we want to try to build capacity building how to grow organic. So, we've been training a lot anyway. There are about 20 residents and there are 60 local children that we train for free".

Aside from the farming, Hoshizora Foundation also collaborates with the surrounding community by provides homestay for guests who want to stay at Kalakijo Tourism Village. The community also provide rooms in their home while facilities such bed provided by Hoshizora Foundation. This stem from many of people from abroad wanted to visit children of Hoshizora Foundation and also wanted to experience village life. The homestay package includes breakfast provided by the host. The guests can experience the rural life and daily activities of the community. The activities are tailored to visit various potentials in Kalakijo Village such as emping, batik, and handicraft, as expressed by Nina, Coordinator of EEC:

"We also have guest house, this guest house involve the community around here. So, if there is any guest, later on they will stay with the community just like the member of the community. There are 12 beds spread around Kalakijo. Therefore, basically we are packaging the tour as village tour. Where the activity is all the same that you invite them to do visiting to Adik Bintang school. For example, if they come from Japan we will give them some space to teach Japanese, watching the making of batik, emping around here"

To attract community participation, Hoshizora Foundation works with active citizen as community organizer in Kalakijo Village. The team management comes from outside of Kalakijo Village so the coordination with the community organizer can help to approach the 
community especially in delivering the programs that will be implemented. Community organizer is someone who knows the citizen of Kalakijo Village very well and has capability to communicate properly. One of the person who help EEC in the early phase is Mr. Aris, he said:

"I did my action by giving an example. For example, they got embarrassed to cut the grass, i will cut the grass. I lift stuffs. So they won't be embarrassed anymore. 'Ah, he did that so why did I don't want to do it as well? So it is like to provoke them. We talk less and do more"

Working with the community is a challenge in running an entrepreneurship. There are a lot of ideas and thoughts from each member. Sometimes working with community make us cannot implement $100 \%$ a strict professional rule. However, a clear agreement such written Memorandum of Understanding (MoU) is necessary to prevent and avoiding a misunderstanding. Till this present days, Hoshizora still capable in addressing those problems. As revealed by Tanti, the HRD Manager of Hoshizora Foundation:

"Every journey has challenges that will make us smarter. Surely by collaborating with community will make the management cannot be done professionally $100 \%$. When we enter an office, there is a standardized system, the basic rule for the staffs. That is the good thing when we hire someone professionally however if we want to involve community, the management should be smoother because their various ideas, various kind of person. Combining it need should be done slowly and carefully. That is the biggest challenge, more into local community, but so far we can cope with that".

Since 2010 Hoshizora Foundation has an office in Kalakijo Village that is still in rural area. The other challenge is in solving the perception of the community about Hoshizora Foundation. Hoshizora Foundation is an $\mathrm{NGO}$ that works in education field so that the funds of it is used to support the education for less fortunate children financially. That funds are not for running entrepreneurship. Those challenges did not make the will of Hoshizora to help each other stop.

In August 2016 until Mei 2017, EEC joined UNLTD Incubation Program from UNLTD Indonesia. This program is incubation for social enterprise for one year. From this program EEC joined various workshop such leadership, impact planning, marketing, financing, investment. There is mentoring from the incubation program where EEC has a mentor to give suggestion in business development. EEC also has an opportunity to receive a grant from Ashmore Foundation for handbook arrangement and publishing.

Handbook is part of EEC curriculum that becomes featuring product from EEC. This handbook project is to improve the quality of EEC service. This Handbook also became promotional tool of EEC program. In June 2017, 21 schools in Yogyakarta have been introduced to EEC programs. There is no specific curriculum in school to raise issues on environmental education through learning life cycle of plants. EEC provides students an education program in open nature that is integrated with the school curriculum. School that joined EEC Curriculum learn about nature in 10 meetings and complement materials farming that do not exist in elementary school level public curriculum. The student will be introduced to environmental education in a more systematic way. As expressed by EEC Team:

"The model that we found is $\mathrm{B} 2 \mathrm{~B}, \mathrm{Business}$ to business with school. So what is the product? The product is EEC curriculum. So now the curriculum for 1 grade until 6 grade. That is the product sold by EEC. Therefore even if the grden is not accessible, we still have a product that we can bring to the schools and conduct it in other lands. So it actually summarize the things that EEC done".

Running entrepreneurship for non-profit organizations is not easy. Organizations that are used to deal with education for underprivileged children then turn into entrepreneurship are such a new learning for them. The limited human and capital resources are also experienced by the Hoshizora Foundation. Collaboration can help the development of entrepreneurship initiated by non-profit foundation. In addition, collaboration can be run with the private sector and the surrounding community. Moreover, collaboration can also expand the impact of entrepreneurship.

\section{CONCLUSION}

Collaboration with other parties play a very important role in providing entrepreneurship even though entrepreneurship become the main goals for the sustainability of the nonprofit organization. The limited resources such capitals, human resources in the management of entrepreneurship initiated by NPOs can be helped by collaborating with other parties included the community. The existence of participation can provide an opportunity to increase the income and knowledge of the communities involved. Aside from individual roles that exist in Hoshizora Foundation, community contributions also help entrepreneurship to survive and thrive. Collaboration in selected entrepreneurship is expected to expand the impact not only for foundation but also for the welfare of the society.

\section{ACKNOWLEDGMENT}

We sincerely thank Hoshizora Foundation especially Environmental Education Center Team for providing us great opportunity to do our research. 


\section{REFERENCES}

[1] J. Midgley, Social Development: Theory \& Practice, New Delhi: SAGE Publications Scanlon, 2014

[2] E. R. K Singh and E. N. Singh, Re-Inventing NGOs as Social Enterprises: A Manipur Perspective, Journal of Entrepreneurship and Management. Volume 3 Issue 1, 2014

[3] S. L. Mozos, I. R. Duarte and A. R. Ruiz. Resource Dependence In Non-profit Organizations: Is It Harder To Fundraise If You Diversify Your Revenue Structure? Voluntas Volume 27, Issue 6, 1 December, pp 2641-2665, 2016

[4] G. Berman, R. Brooks and J. Murphy, Funding the Nonprofit Welfare Sector: Explaining Changing Funding Sources, 1960-1999. Economic Papers, 25(1), pp 83-99, 2006

[5] H. M. Morris, S. Coombes, M. Schindehutte and J. Allen, Antecedents and Outcomes of Entrepreneurial and Market Orientations in a Non-Profit Context: Theoretical and Empirical Insights, Journal of Leadership and Organizational Studies 13 (4): 1239,2007

[6] S. Khieng and H. Dahles, Commercialization in the Non-Profit Sector: The Emergence of Social Enterprise in Cambodia, Journal of Social Entrepreneurship, 2014

[7] W. L. Tan and S. J. Yoo, Social Entrepreneurship Intentions of Non Profit Organization, Journal of Social Entrepreneurship, 6:1, pp 103125,2015
[8] N. Kapucu and F. Demiroz, A Social Network Analysis Approach to Strengthening Nonprofit Collaboration, The Journal of Applied Management and Entrepreneurship, Vol. 20, No. 1, 2015

[9] N. Kapucu, M. A. Augustin and M. Krause, Capacity Building for Community-based Small Nonprofit Minority Health Agencies in Central Florida, The International Journal of Volunteer Administration, XXIV (3), pp 10-17, 2007

[10] N. Araniri, "Implementation of Community Entrepreneurship Empowerment Stage Through Community Development Program Zona Madina Dompet Dhuafa in Jampang Village, Kemang Subdistrict, Bogor Regency" (Implementasi Tahapan Pemberdayaan Kewirausahaan Masyarakat Melalui Program Community Development Zona Madina Dompet Dhuafa di Desa Jampang, Kecamatan Kemang, Kabupaten Bogor), Jakarta: Universitas Islam Negeri Syarif Hidayatullah, 2016

[11] B. Wicaksono, "The Role of Kreativitas Unit Usaha Muslimah (Kuntum) Indonesia Foundation in Reducing Unemployment Through Social Entrepreneurship Practice In Tegalwaru Village, Ciampea-Bogor" (Peran Yayasan Kreativitas Unit Usaha Muslimah (Kuntum) Indonesia dalam Mengurangi Pengangguran Melalui Praktik Kewirausahaan Sosial Di Desa Tegalwaru, Ciampea-Bogor). Jakarta: Universitas Islam Negeri Syarif Hidayatullah, 2016

[12] L. Wijayanti and F. Nugroho, Social Development Through Entrepreneurship with Community Participation Initiated by Nonprofit Organization, unpublised 